\title{
Conceptual and Theoretical Basis of Integration of Elements of Different Time Periods in the Historic Environment of Small Towns
}

\author{
Ievgeniia Zapunna, National Aviation University
}

\begin{abstract}
The article refers to the means of harmonious combination of elements of different time periods and space-planning of environment, improvement and revival of memorable architectural heritage of urban environment, creation of comfortable living conditions etc. The formation of such means is based on the development of conceptual and theoretical model of integration process. Thus, the aim of the paper - is to identify effective approaches to regeneration of historical environment of small Ukrainian towns.
\end{abstract}

Keywords - Term "integration" in urban planning, the model of integration process, regeneration and renewal of historical urban environments, small Ukrainian towns.

\section{INTRODUCTION}

Many scholars believe that space and town planning features of originality are most vividly traced in small towns. They constitute the most numerous category of settlements in the world, including Ukraine. Their stable economic development is the key to the prosperity of the society. That is why one of the key issues of modern urban planning is the renewal of material centres of historical urban space of small towns through emphasizing their identity simultaneously overcoming social inertia.

Methodological basis and methods of this research were chosen to solve the tasks of this research aimed at improving the urban environment of small historic Ukrainian towns. In particular, theoretical sources and practical experience regarding the improvement of the historical urban environment were processed using methods of analysis, synthesis and generalization. Modelling method was used in the development of conceptual and theoretical models. It will facilitate the practical implementation of scientifically grounded theoretical foundations.

I. Factors that Affect the Process of Transforming the Space-Planning Structure of the Historic Centre

Improvement and humanization of urban space settlements is a multilayered process, in which people, material objects, space, information, symbols and signs interact. It is difficult to consider all existing aspects of heterogeneous essence of urban space. However, we need to identify the main factors that most significantly affect its transformation. In order to specify the factors, we have analyzed practical experience of renewal and humanization of the historical environment of towns and identification of the most flexible elements of historical space that can affect its improvement.
It has been found that the adherence to the principles of sustainable development concept is effective in the process of improving urban environment [4], [5, 14-19]. According to the recommendations of the "Istanbul Declaration" 1996, harmonious development is seen in the transformation of urban space in ecological, socioeconomic and cultural spheres. The content of the provisions of sustainable development concept has helped to specify the factors affecting the improvement of historical environment of small towns.

It has been established, that in order to identify the most flexible elements that improve historical space, relatively stable and variable structural elements in urban fabric should be determined. The relatively stable elements include the planning structure, natural landscape, as well as visual connections between them $[1,34],[2,152,157],[3,20]$. They take extremely active part in the formation of originality of a settlement, they can create an integrated architectural and artistic image. Variable elements of urban environment include fragments of construction, providing of public amenities, elements of promotional materials, paving and planting. Therefore, their renewal within a short period of time has a positive impact on urban environment.

We have distinguished such factors as architectural and urban planning, natural and landscape, socio-cultural factor, engineering and communication. They take into account the features of visual, psychological and sensitive comfort of a person in urban environment in full and have the strongest influence on its transformation.

\section{Features of the Use of Term} "Integration" in Urban Planning

Although the semantics of the word "integration" is close to urban terminology system, there is still neither a clear definition nor a theoretical mechanism for its application inthe particular case. The analysis of scientific literature has shown that the term "integration" in publications appears in various capacities: as a program of actions, as a phenomenon, as a principle or as a process that shows the flexibility of its meaningful interpretation. Therefore, it is necessary to clarify the meaning of the term "integration" and develop a theoretical basis for its application in the Ukrainian town planning. It is suggested that "integration" is considered as a process of implementation of coordinated actions on the integration object focused on the achievement of a specific function or a set of functions. These functions are artistic and aesthetic, informative and significant features of urban environment, 
its comfort, environmental friendliness, etc. The development of effective approaches of harmonious combination of historical and modern space and planning structures will contribute to the cultural revival of settlement and preservation of historical and architectural heritage. In order to determine the main parameters, under which the said harmonious transformation of historical urban environment should occur, the model of integration process, which involves the following steps, is offered (Fig. 1):

- $\quad$ specification of integration object;

- formulation of goals and objectives of the integration process of different time periods, planning and space elements in historical urban environments;

- preparation of recommendations in order to achievethe goal;

- analysis of hypothetical result of the implementation of design solutions;

- consideration of the stated proposals in pre-design activity and design.

\section{Structure of Model of Integration}

The stage of preparation of recommendations in terms of the ways to integrate the elements of different time periods, space and planning in historical urban space was the result of consistent implementation of previous stages.

The object of integration were the elements of different time periods, space and planning of urban environments, such as historical street tracing, architectural heritage and landscape gardening of the area. It has been established that their harmonious combination will provide the appropriate level of arrangement of subject and space, historical and cultural, emotional and aesthetic and functional and space content of the historical environments.

The purpose of integration of elements of urban space of different time periods is the reorganization of urban space of small towns, which is aimed at adapting the elements of different time periods, planning and space of the historical environments to current social and economic realia. It is important to develop artistic and informative "verbality" of architecture, enhance positive emotional and psychological impact on people thus stimulating the interest in historical and national traditions. The statement of problems of integration process includes the following pre-determined factors:

- $\quad$ preservation and updating of historical and cultural heritage, enhancement of visual information content for its active participation in the functional and activity-related relationships of historical environments;

- development of appropriate technical design and informative and significant content;

- $\quad$ taking care of green planting and water bodies;

- cleaning and restoration of water ponds, soil and vegetation cover;

- active involvement of rivers and reservoirs in the system of park territories;

- active involvement of shopping centres, cultural, cultural and informational, entertainment and tourist and informa-

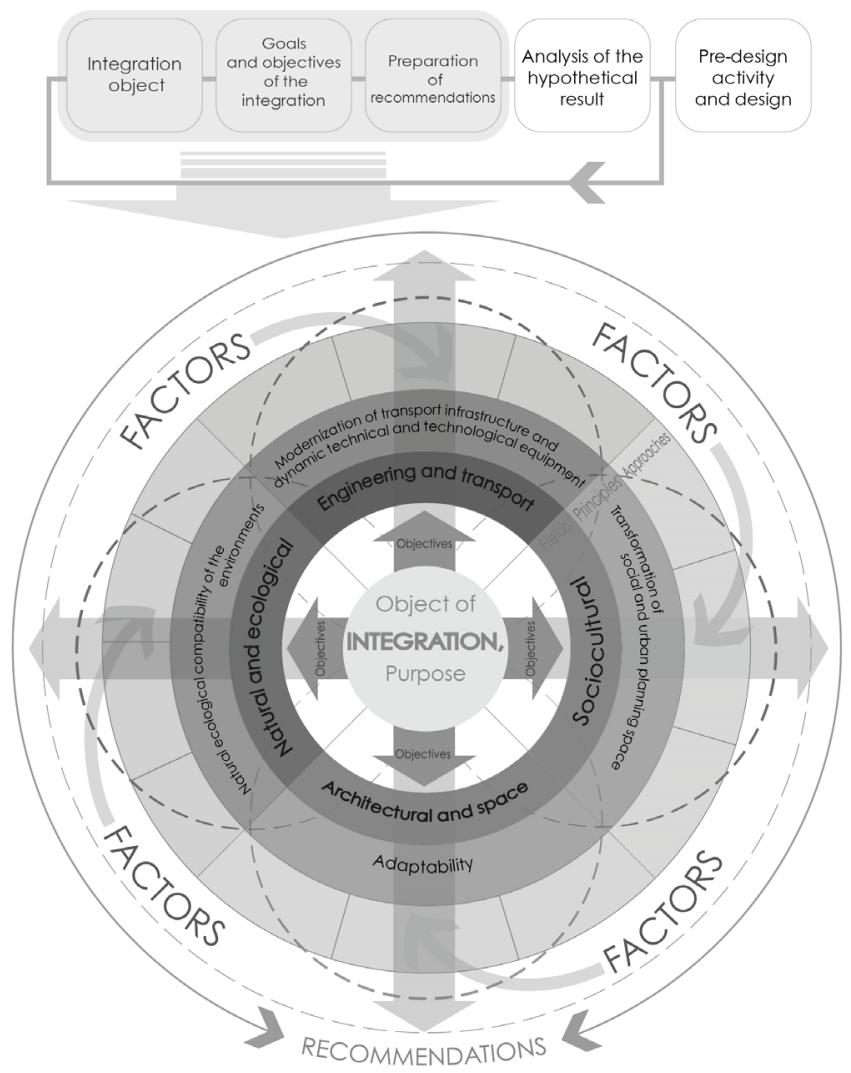

Fig. 1. Preparation of recommendations of integration of space-planning elements of different time periods into historical urban environments [Ievgeniia Zapunna].

tion content of urban environments that take into account age peculiarities;

- active involvement of shopping centres, cultural, cultural and informational, entertainment and tourist and information content of urban environments that take into account age peculiarities;

- $\quad$ arrangement of the system of pedestrian areas and bike trails;

- intensification of social contacts and areas of interaction;

- development of safe and comfortable road and transport infrastructure and related services, etc.

The tasks, summarized according to the modern vision of harmonious and comfortable urban space, provide for interconnection of natural, human-caused and social subsystems. They conduct the transformation of urban environments through a set of characteristics. The spheres of influence, typical of each of the subsystems, are called "fields". The model of integration process includes four fields: architectural and space integration field (IF), natural and ecological IF, socio-cultural IF, engineering and transport IF. They were identified at the stage of preparing recommendations and determined further structure of the model. The developed model of integration process is based on balancing of the ways of versatile improvement of component structure of the historical environments of the town of different 

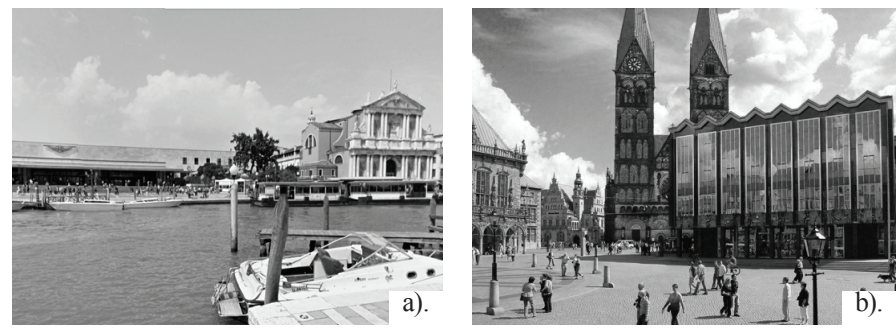

Fig. 2. a - Prototypes of the approach of emphasis architectural ensemble of waterfront, Venice; b - Parliament of Bremen [9], [10].
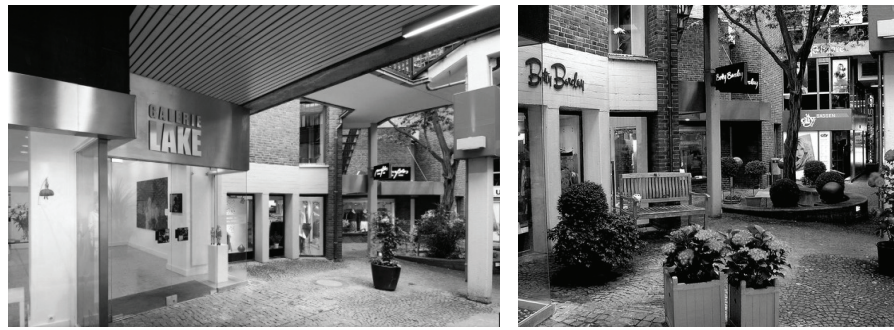

Fig. 4. Prototypes of the approach of interior and flowing spaces: Herbartgang St., Oldenburg [13].

time periods and the renewal of its image. The model involves the identification of key principles that stem from each of the above-mentioned IF (Fig. 1):

principle of adaptability;

principle of natural ecological compatibility of the environments;

principle of transformation of social and urban planning space; principle of modernization of transport infrastructure and dynamic technical and technological equipment.

The approaches, the prototypes of which were found in the global urban planning, have been defined for each of the developed principles (Fig. 2) - (Fig. 14). Unfortunately, they almost have not been applied to the small historical towns in Ukraine.

The principle of adaptability provides visual and image bearing (external) and functional (internal) transformation of historical and cultural heritage. The first one is aimed at the harmonious stylistic symbiosis of architectural and historical centres. The second one is focused on shaping the model of their development according to the basis of modern environments vital for the society. The combination of historical and modern architecture makes it possible to create a unique tonality of urban space with inherent contrasts, compositional emphasis and unexpected architectural plasticity. However, expressive forms should be easily understood given the psychophysical human orientation in space, stimulate holistic aesthetic and cultural ideals. At the same time, the town should be comfortable, provide the residents with protection and also make them happy [6, 38].

Thus, analyzing the experience of foreign countries in aestheticization and humanization of urban environments it has been found that the expressiveness of urban space arises in the situation of complementarity of modern and historical space and
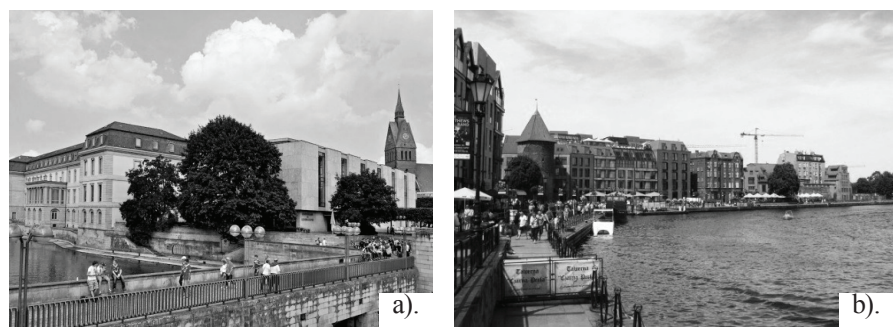

Fig. 3. Prototypes of the approach of dialogue: a - Landtag of Lower Saxony, Hannover; b - waterfront of old city, Gdansk [11], [12]
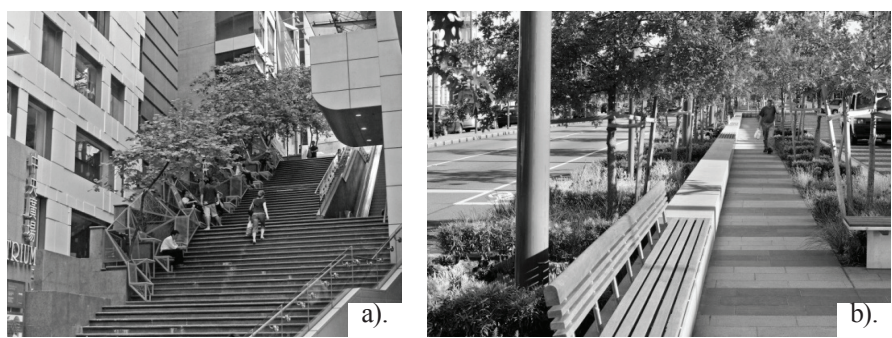

Fig. 5. Prototypes of the approach of most effective use of natural and human-made surfaces: a - mini-stair park Cascade in Hong Kong; b - Lonsdale St., Dandenong City [14], [15]

town planning elements, which are based on a wide variety of artistic and stylistic expression. On the one hand it appears in the maximum visual approach through variations of form and scale, such as the historical centre of Gdansk. On the other hand, it appears in contrasting contraposition of architectural plasticity in forming a harmonious ensemble illustrating the Santa Lucia Station in Venice.

Saturation of architectural sites with current functional content is also one of the priorities of improving urban environments [7, 5]. Adaptation of memorable objects to modern functional and activity-related processes was considered by A. Ganeshin [8]. The scientist offered to implement it on the basis of heredity and generality of functional and technical processes that are subject to the type of transformation (external/internal) that corresponds to the surrounding urban situation $[8,38]$.

Following the principle of adaptability, the approaches of emphasis, dialogue, interior and "flowing" spaces have been established.

\section{1). Approach of emphasis}

It is characterized by form-building complicacy or, conversely, minimization of decoration and plastic transitions; it is distinguished by visual separation of an object (historical/modern) or their group in the urban environments compared to others.

\section{2). Approach of dialogue}

It is characterized by affinity of approaches to architectural shaping, promotes visual similarity of objects, harmony and compellability of building in different time periods; compliance of the direction of functioning with the location.

3). Approach of interior and flowing spaces

It is characterized by plastic combination of public and private spaces, contributing to the creation of chamber scale, psycholog- 

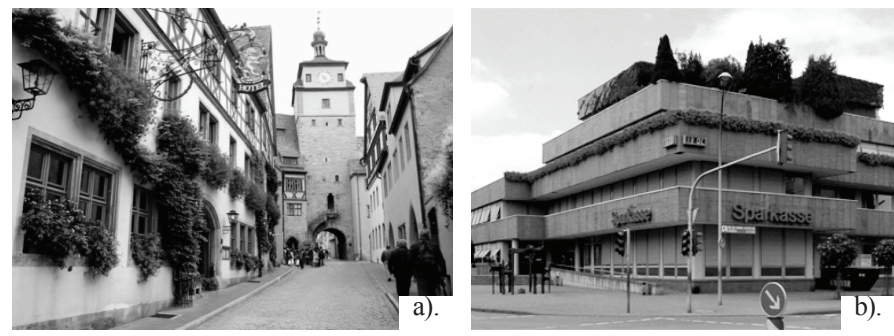

Fig. 6. Prototypes of the approach of phyto-correction and biodiversity a) street floristic in Rothenburg; b) floristic decor on Bahnhof St., Steinfurt [16], [17].
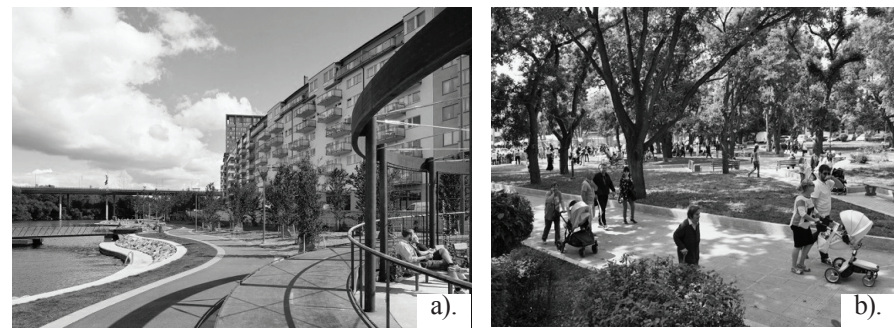

Fig. 8. Prototypes of the approach of recovery and regeneration of green area, water and green landscapes: a)embankment, Stockholm; b) the Borisova Gradina Park, Burgas [20], [21].

ically close to people, as it is associated with the continuation of individual residential zone. This environmental transformation of urban environment creates a sense of security of an individual, not allowing him/her to lose orientation points.

The principle of regulation of natural ecological compatibility of the environments is aimed at increasing the priority in the development and protection of the surrounding environments, regeneration of potential landscape and environmental and recreational centres. The development of greening of a frame is an important element of urban planning structure that performs environmental, aesthetic and recreational functions. Following the principle of regulation of natural ecological compatibility of space, the following four approaches have been offered:

1). Approach of the most effective use of natural and human-made surfaces (vegetable mould, elements of architectural buildings)

It is characterized by decreasing the surfaces covered with concrete and asphalt and replacing them with eco-friendly materials; planting of greenery, shrubs and trees with regard to suitability for these places: in public gardens, along sidewalks, on accessible roof areas, by the entrance lobbies to the building, on the balconies of buildings, in flowerpots on pedestrian areas, etc.

2). Approach of phyto-correction and biodiversity

It is characterized by arranging expressive compositions of lawns and flower beds; improvement of a range of green phyto-active planting, selecting expressive combinations of vegetation in form, colour, volume, etc.

3). Approach of application of vertical garden

Vertical "biological decor" is arranged by means of the socalled "vertical garden" that provides the plants with vital func-
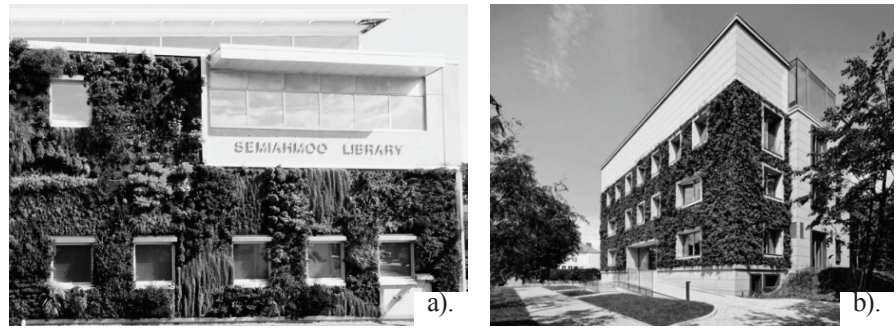

Fig. 7. Prototypes of the approach of application of vertical garden: a) Surrey Semiahmoo Library; b) office building in Warsaw [18], [19].
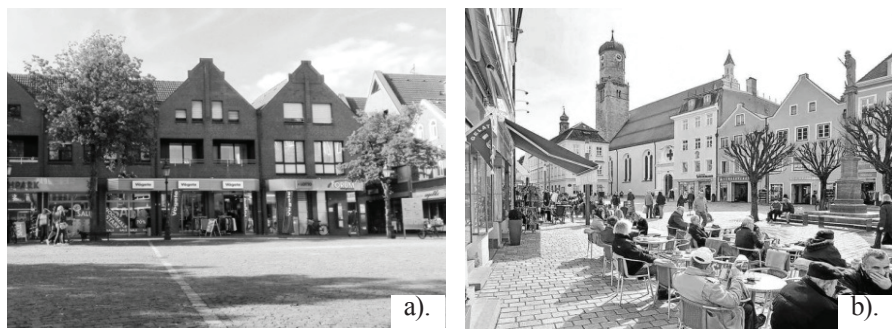

Fig. 9. Prototypes of the approach of space saturation with centre-forming elements: a) Market Square in Ludinghausen; b) Market Square, Weilheim In Oberbayern [22], [23]

tions or traditional setting of containers with plants that climb near vertical structural elements.

4). Approach of recovery and regeneration of green area, water and green landscapes

It is characterized by solicitous attitude and taking care of existing vegetation: improvement of park and garden paving of alleys and sites; compliance with ecological properties of materials applied and park furniture; improvement of quality and updating of the elements of public welfare, formation of incoming groups, landscape design and more. The approach is aimed at reconstruction of water and coastal territories: cleaning of the coastlines of rivers and reservoirs; establishment of observation platforms and coast alleys for walks, beach equipment upgrade.

The principle of transformation of social and urban space is aimed at reproduction of sense of community and establishment of entire socio-cultural formation that synthesizes spiritual value orientations of the residents of the town and hierarchy of their consumer priorities and recreation. Therefore, the main objective of efficient functioning of the historical environments in that respect is active involvement of people in interaction with urban space and information reference that it bears, as well as help to overcome the language barrier in communication with each other. In view of the above, several approaches, the first of which should contribute to the human mobility within the historical centre, have been formulated:

1). Approach of space saturation with centre-forming elements

It is provided by brining functional facilities into the historic space of high variety of elements that ensure utilitarian and consumer, psychological and physical, informational and cultural life processes. An important aspect of their functioning should be twenty-four-hour usefulness in the town life, which 

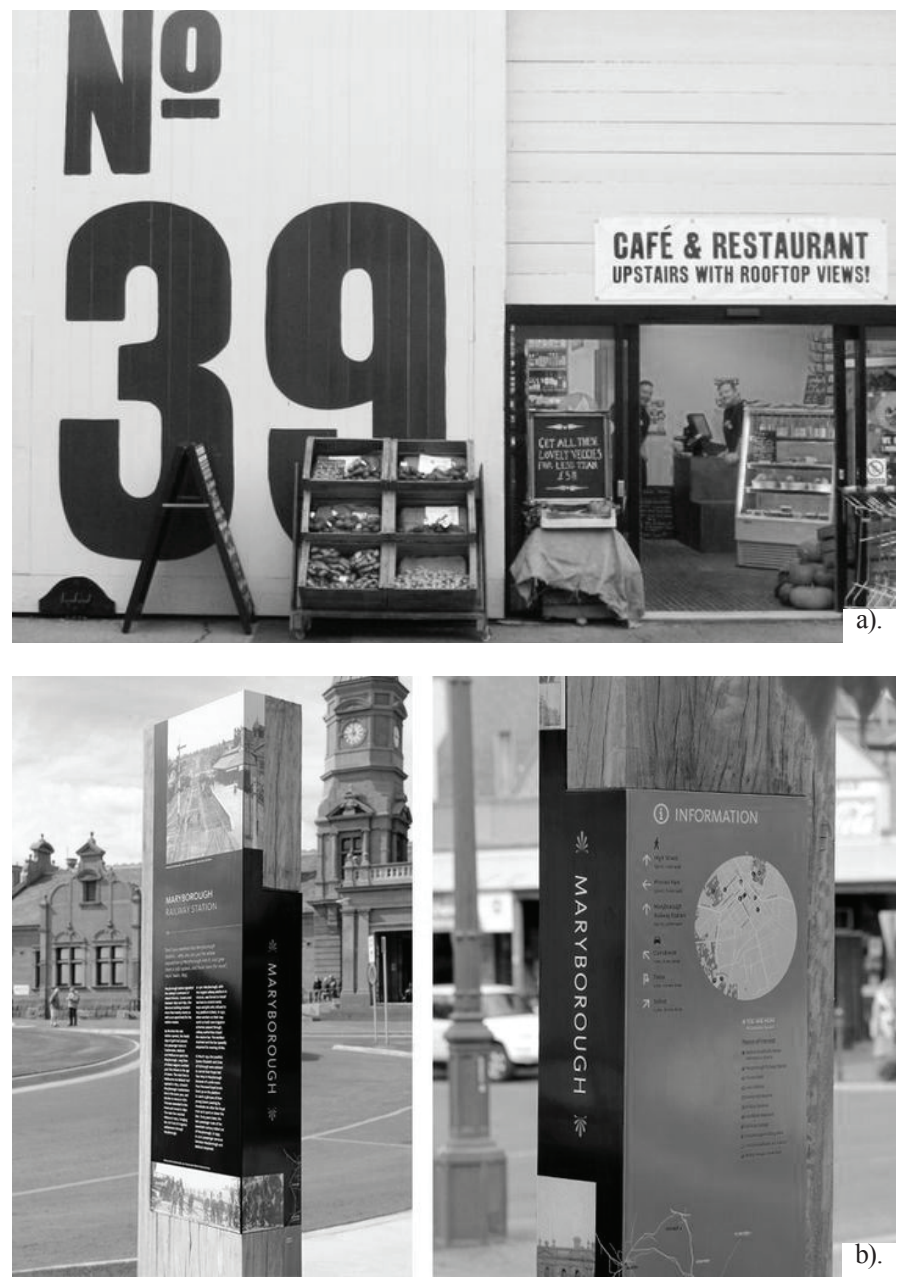

Fig. 10. Prototypes of the approach of space saturation with centre-forming elements: a) an alternative approach to numbering of buildings; b) information stele, Maryborough [24], [25].

would create the "popularity" of cultural space of the historical part of the town.

2). Approach of space saturation with centre-forming elements

It is needed for the numbering of buildings (including unusual approaches), formation of light information communications and landmarks in the town, placement of the map, indicating memorial sites and historical information on them, at the control points of urban frame. It is alsothe design of integrated light and colour silhouette of historical space that simultaneously increases the attractiveness and recreational capacity of the environments.

\section{3). Approach of interactivity}

It is characterized by active participation of people in the formation of environment. This approach is offered to be conducted through the creation of communication tools, which must respond to human actions and be implemented on the basis of "clear" for people scenario that provides a specific result. The basis of the approach is the involvement of people in communication, interest in the urban space "study".

The principle of modernization of transport infrastructure and dynamic technical and technological equipment is
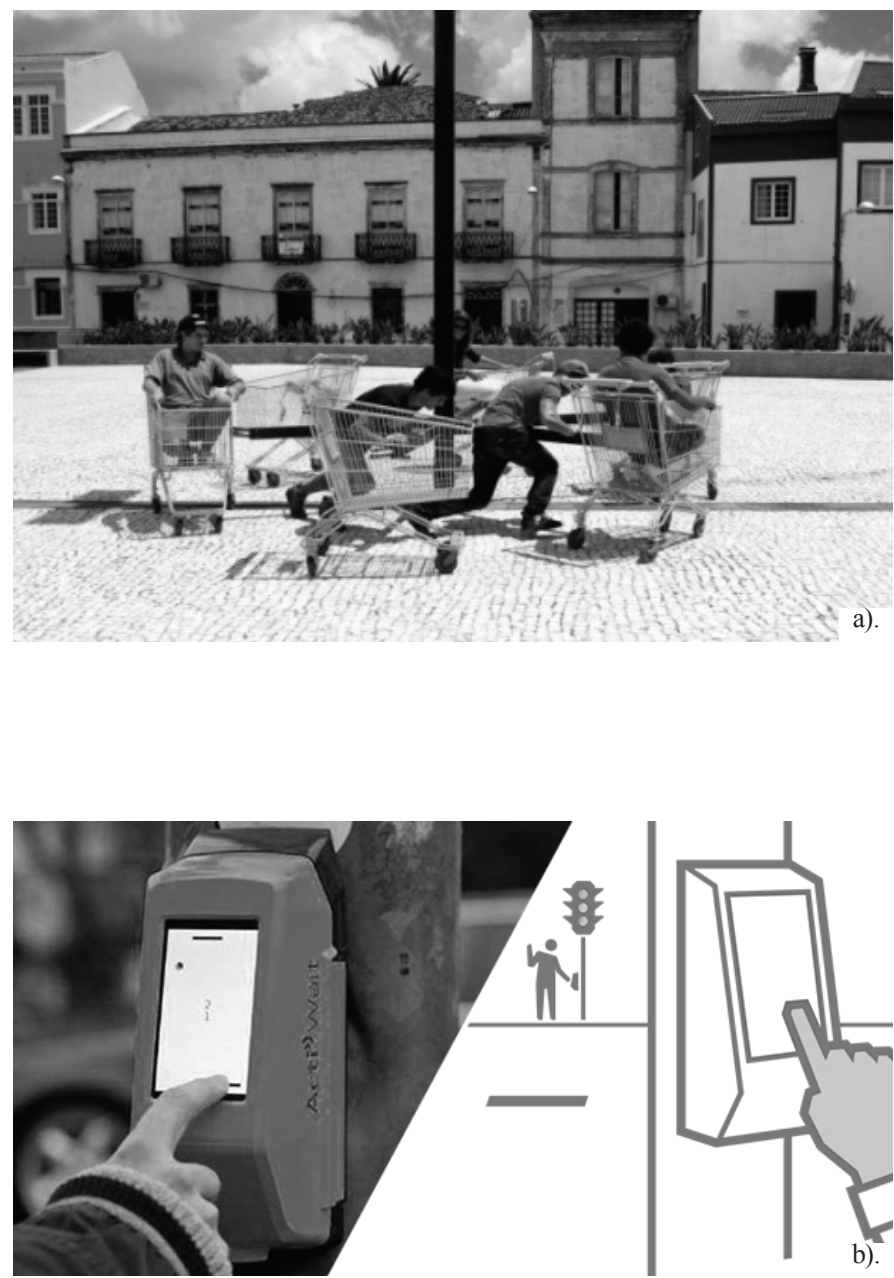

Fig. 11. Prototypes of the approach of interactivity: a) Urban Carousel, Ponta Delgada; b) street-pong in Oberhausen [26], [27].

seen in the combination of different types of transport, optimal material and technical basis of pedestrian and transport complex of Ukrainian towns, creation of favourable conditions for bicycle transport, ensuring the development and wide application of modern technologies of resource and energy conservation. A number of approaches aimed at integrated improving of the conditions of operating, visual and aesthetic qualities of the roads and their convenience for all types of transport communication, have been defined.

1) Approach of increase in comfort and safety for all road users

It is characterized by the organization of the complex of various practical and technological means, as well as elements of road improvement, to make transport infrastructure better in the town and outside it (Fig. $12 \mathrm{a}, \mathrm{b}$ ).

2). Approach of aestheticization of highways and adjacent landscape

It is focused mainly on countryside areas and involves the organization of visual and sensory comfort of movement, because the road is "an original information channel, which people, who receive visual information about the surrounding area, move 

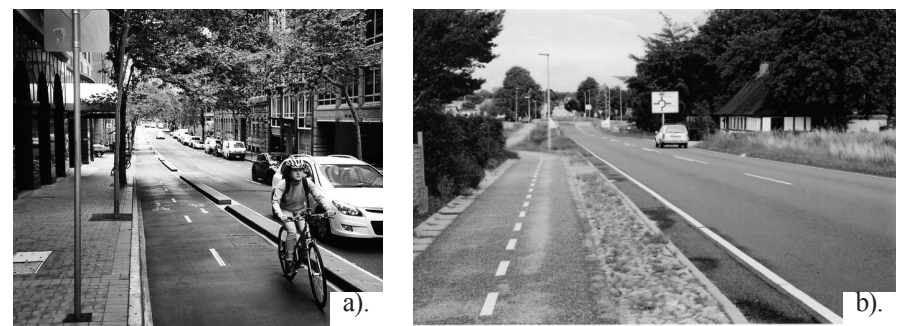

Fig. 12. Prototypes of the approach of increase in comfort and safety for all road users: a) road cycling, Ottawa; b) car and bike lanes in the suburbs of Copenhagen [29], [30].
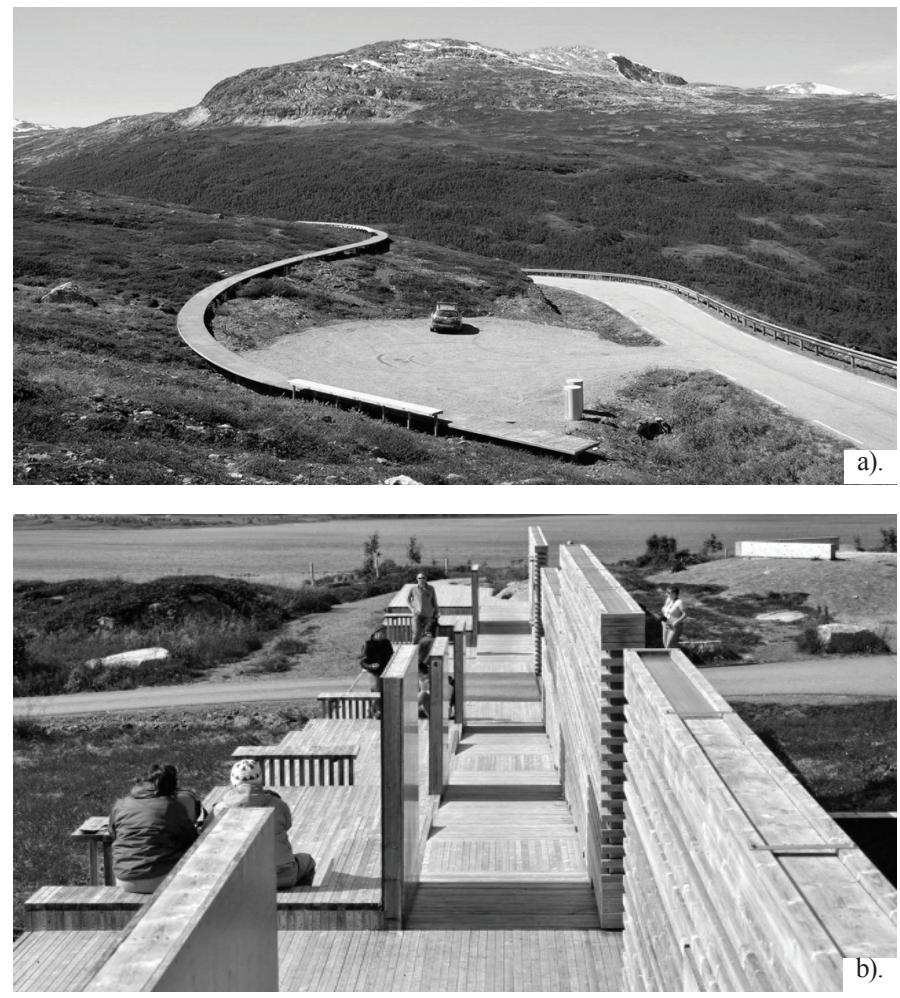

Fig. 13. Prototypes of the approach of aestheticization of highways and adjacent landscape:a) observation platform, Norway; b) recreation area, Lofoten Islands [31], [32].

on ..." $[28,51]$. The application of the approach would improve aesthetic and functional qualities of the road (Fig.13 a, b).

3). Approach of creating expressive architectural and lighting image

It is characterized by the use of energy efficient lighting sources and their structural modelling in the places of concentration of architectural heritage, greenery, picturesque landscape elements, water surfaces and elements of the pedestrian zone: windows, small architectural forms, elements of urban land improvement, sidewalks and more. The implementation of the approach is achieved by establishing permanent or temporary installations of external architectural lighting, namely, the systems of local or dynamic (multi-mode) light and colour; luminous surfaces; "light graphics", or their combination.
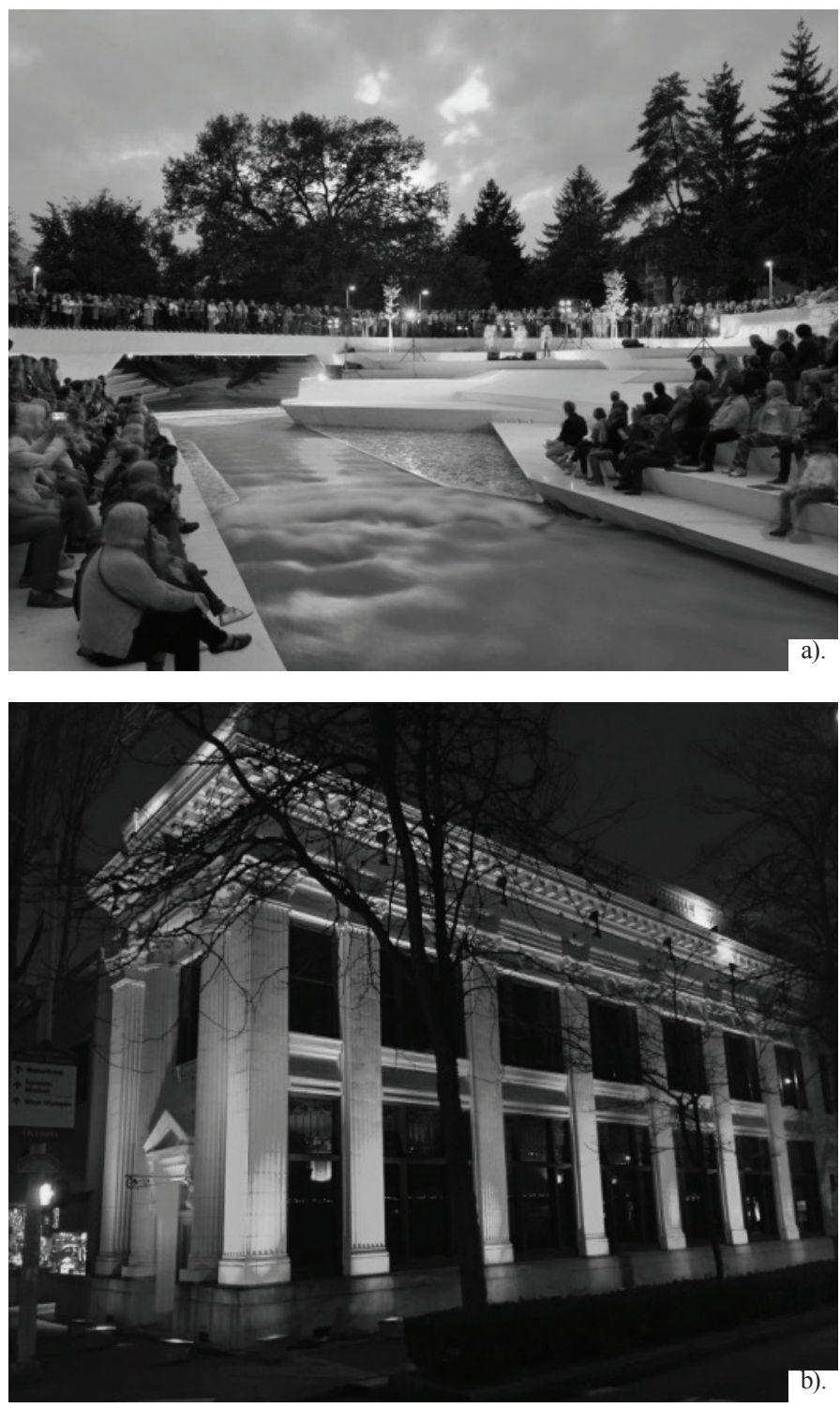

Fig. 14. Prototypes of the approach of creating expressive architectural and lighting image: a) the Velenje "Promenada" lighting; b) architectural lighting of Olympia National Bank Building, Washington [33], [34].

\section{Conclusion}

We consider that the term "integration" can be a part of urban terminology system, common in Ukraine. In addition, the implementation of theoretical recommendations will be effective while applying an integrated approach to regeneration of historical urban space of Ukrainian towns in general and Western Ukrainian settlements in particular, such as Busk, Berezhany and Zolochiv. It was offered to consider the term as a process of holistic harmonious approach to urban environments, saving of valuable architectural and urban heritage in the light of their adaptation to the current needs of society.

As a result of gradual development of the existing theoretical model of integration process of historical planning and space elements in modern urban structure, theoretical tools of harmo- 
nious combination of elements of different time periods, space and planning of the environments, improvement of historical urban space, its humanization have been specified. Thus, approaches have been formed relating to different areas of urban environment:

- $\quad$ approach to economically sustainable development of a settlement through the development of tourism services;

- $\quad$ increase in physical and visual comfort of people in historical space and their orientation in it;

- $\quad$ search for modern means of socialization and communication of urban population;

- formation of ecological balance of the territory through creating natural landscape of natural frame;

- improvement of the conditions of human movement within the town and creation of effective transport communication.

The proposed approaches will contribute to the formation of recommendations for versatile space improvement of historical towns.

\section{REFERENCES}

1. Report of the World Commission on Environment and Development : Our Common Future. New York: Oxford University Press, 1987 [online, cited 02.09.2016]. http://www.un-documents.net/our-common-future.pdf

2. Posatsky, B. Prostir mista i miska kultura : na zlami $X X-X X I$ stolit. Lviv: Lvivska politekhnika, 2007. 207 p.

3. Sedak, A. Gradostroitelnyie printsipyi sohraneniya i sovershenstvovaniya istoricheskoy sredyi malyih gorodov : na primere gorodov zapadnyih oblastey USSR. Kiev, 1987. 206 p.

4. Oleynik, E. Prostranstvenno-planirovochnaya organizatsiya istoricheskogo yadra $v$ strukture tsentra bolshogo goroda : na primere zapadnyah oblastey USSR. Kiev, 1989. 231 p.

5. Raninskiy, Yu. Uroki svoeobraziya v arhitekture istoricheskogo goroda Arhitektura SSSR, Vol. 7, 1978. p. 20-24.

6. Zitte, K. Hudozhestvennyie osnovyi gradostroitelsta. Moskva: Stroyizdat, 1993. $256 \mathrm{p}$.

7. Prutsyin, O. Chelovek i arhitekturno-istoricheskaya sreda. Arhitektu ra SSSR, Vol. 2, 1983. p. 4-6.

8. Ganeshin, A. Istoricheskaya sereda: issledovanie i proektirovanie. $A r-$ hitektura SSSR, Vol. 2, 1983. p. 37-39.

9. Google Street view [online]. Google maps [cited 23.09.2016]. https://www. google.com.ua/maps/@45.4404558,12.3221656,3a,75y,322.89h,88.1t/ data $=! 3 \mathrm{~m} 6$ ! $1 \mathrm{e} 1 ! 3 \mathrm{~m} 4$ !1s6eyYxTiUWMtvZsDhT8tlVQ!2e0!7i13312!8i6656

10. Haus der Burgerschaft (State Parliament) [online]. Bremen-tourism [cited 13.09.2016]. http://www.bremen-tourism.de/haus-der-buergerschaft-state-parliament

11. Photo by Michael Schuster [online]. Panoramio [cited 13.09.2016]. http:// www.panoramio.com/photo/94625220

12. Dostoprimechatelnosti Gdanska [online]. Life-globe [cited 20.09.2016] http://life-globe.com/europe/polsha/gdansk/staryj-gorod-gdansk/

13. Oldenburg [online]. Myheimat [cited 10.09.2016]. http://www.myheimat. de/oldenburg-oldenburg/freizeit/herbartgang-m2101808,2409128.html

14. The Cascade Project, Hong Kong [online]. Lemayonline [cited 10.09.2016] http://www.lemayonline.com/en/wow/the-cascade-project-hong-kong

15. Projecto Lonsdale Street, Dandenong [online]. Archdaily [cited 10.09.2016]. http://images.adsttc.com/media/images $/ 5201 / 627 \mathrm{~b} /$ e8e4/4eff/f200/006a/slideshow/BKK 05 DandenongLonsdaleSt JohnGollings.jpg?1375822429

16. Rothenburg! [online]. Panoramio [cited 06.11.2015]. http://www.panoramio.com/photo/14874457

17. Referenzen [online]. Elektro-elfers [cited 10.11.2015]. http://www.elektro-elfers.de/scripts/show.aspx?content=/shop/home/referenz
18. Living wall [online]. Barrydjdphoto.wordpress [cited 12.09.2016]. https:// barrydjdphoto.wordpress.com/2015/05/01/living-wall/

19. A crumbling Warsaw building gets a luscious new green face [online]. Inhabitat [cited 12.09.2016]. http://inhabitat.com/a-crumbling-warsawbuilding-gets-a-luscious-new-green-face/

20. Hornsberds Strandpark [online]. Landezine [cited 3.09.2016]. http://www. landezine.com/index.php/2013/02/hornsbergs-strandpark-by-nyrens-architects/

21. Borisova Gradina - Burgas [online]. Opoznai [cited 10.09.2015]. https:// opoznai.bg/view/borisovata-gradina-burgas

22. Marktplatz Ludinghausen [online]. Allofus [cited 12.09.2016]. http://www. allofus.de/wp-content/uploads/2015/08/IMG_20150731_181257.jpg

23. Urlaub Ausflugsziele \& Sehenswürdigkeiten in Weilheim im Pfaffenwinkel [online]. Bayregio-weilheim [cited 22.05.2016]. http://www.bayregio-weilheim.de/tourismus/

24. No. 39 café [online]. Pinterest [cited 16.09.2016]. https://www.pinterest. com/pin/263601384414060708/

25. Signage [online]. Pinterest [cited 16.09.2016]. https://www.pinterest.com pin/157485318194914930/

26. Urban Carousel [online]. Weburbanist [cited 12.09.2016]. http://weburbanist.com/2013/12/17/urban-carousel-merry-go-round-made-of-shoppingcars/

27. Le streetpong 2.0 [online]. Arobaz [cited 17.09.2016]. http://arobaz.tk/ wp-content/uploads/2015/10/ActiWait.jpg

28. Sardarov, A. Doroga i landshaft. Arhitektura SSSR, Vol. 5, 1983. p. 48-51.

29. Protected bike lane [online]. Pinterest [cited 16.09.2016]. https://www. pinterest.com/pin/368450813246482627

30. Fork in the road as Danish and Dutch-style cycle routes spread [online]. Theconversation [cited 05.02.2016]. http://theconversation.com/fork-inthe-road-as-danish-and-dutch-style-cycle-routes-spread-19744

31. Vedahaugane [online]. Landezine [cited 16.09.2016]. http://www.landezine. com/wp-content/uploads/2011/12/Vedahaugane-by-LJB-07.jpg

32. Torvdalshalsen [online]. Landezine [cited 16.09.2016]. http://www.landezine.com/wp-content/uploads/2010/10/70n arkitektur torvdalshalsen norway_tourist_route_20.jpg

33. Photo by Miran Kambič [online]. Architects [cited 02.09.2016]. http://www. world-architects.com/architecture-news/submitted-works/Velenje_Promenada_2913

34. Architectural Lighting [online]. Pacific stage [cited 02.09.2016]. http:// pacificstage.com/wp-content/uploads/2016/01/IMG_1970-1024x768.jpg 


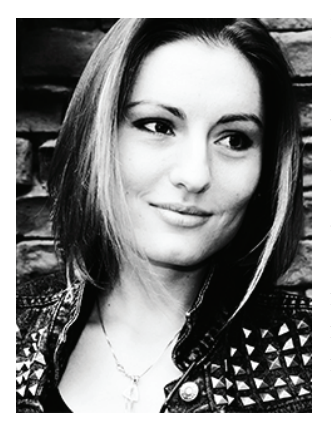

Ievgeniia Zapunna obtained the M. Sc. Arch. degree from Kyiv National University of Construction and Architecture in 2012. Since graduation, she has been active in architectural design practice. Since 2012, she has been a doctoral student the Faculty of Urban Planning of National Aviation University in Kyiv.

She is an Assistant with the Faculty of Urban Planning of NAU, since 2016. She has taken part in five research and practical conferences and one International Research and Practical Congress in Kyiv.

She is the author of the article "Types of Planning Structures of Small Historic Towns of Ukraine" in the academic journal Science - Future of Lithuania.

Her research areas are regeneration and renewal of Ukrainian small Magdeburg-law towns, aestheticization and humanization of historical centres, integration of space-planning elements of different time periods into historical urban environments.

\section{Contact Data}

\section{Ievgeniia Zapunna}

National Aviation University

Faculty of Urban Planning

Address: 1, Kosmonavta Komarova Ave, Kyiv 03058, Ukraine

Phone: +38 (044) 40668 02, +38 (044) 4067976

E-mail: ptp@nau.edu.ua 